\title{
PROBLEMATIKA KONSEP BENTUK BUMI DAN UPAYA MENCARI TITIK TEMUNYA DALAM PENENTUAN ARAH KIBLAT
}

\author{
Reza Akbar \\ Institut Agama Islam Sultan Muhammad Syafiuddin Sambas \\ e-mail: reza_akbar34@yahoo.com \\ Riza Afrian Mustaqim \\ Universitas Islam Negeri Ar-Raniry Banda Aceh \\ E-Mail: rizaafrian63@gmail.com
}

\begin{abstract}
ABSTRAK
Salah satu isu sains yang sedang berkembang akhir-akhir ini adalah perdebatan antara penganut teori Bumi bulat (sferis dan ellipsoid) dan penganut teori Bumi datar (flat earth). Persoalan ini menjadi masalah yang sangat serius karena masing-masing pihak tidak hanya menunjukkan bukti ilmiah, tetapi juga menggunakan dalil al-Quran dan hadis untuk memperkuat argumentasi mereka. Dari segi sains, penganut Bumi datar memberikan argumentasi bantahan terhadap teori Bumi bulat seperti tidak terlihatnya lengkungan Bumi berdasarkan eksperimen Samuel Robotham, klaim yang menyatakan bahwa NASA merekayasa foto Bumi dan satelit adalah kebohongan semata, tidak adanya grafitasi, kutub utara merupakan pusat Bumi dan lain-lain. Sedangkan dari segi nash syar'i, para ahli tafsir pun berbeda pendapat tentang bagaimana bentuk Bumi sebenarnya. Apa yang dikemukakan oleh penganut flat earth pun selanjutnya ditanggapi oleh penganut Bumi bulat dengan sejumlah argumentasi ilmiahnya. Penelitian ini merupakan penelitian kepustakaan (library research) yang bertujuan mendeskrpsikan problematika teori Bumi bulat dan Bumi datar dan menjelaskan upaya mencari titik temunya dalam penentuan arah kiblat. Dari problematika tersebut, diajukanlah sebuah metode penentuan arah kiblat yang diduga bebas dari pengaruh bentuk Bumi, apakah datar atau bulat yaitu rashdul kiblat tahunan.
\end{abstract}

Kata Kunci: Arah kiblat, Bumi datar, Bumi bola, rashdul kiblat

\section{PENDAHULUAN}

Dunia sains saat ini sedang disuguhkan tantangan dan kritikan yang cukup serius dengan adanya pemahaman flat earth atau paham Bumi datar. Menurut sebagian kalangan, paham ini dianggap cukup meresahkkan karena bertentangan dengan pengetahuan dan sains yang selama ini dianut bahwa Bumi itu bulat. Selain itu, tantangan ini tampaknya memiliki kekuatan dari sisi argumentasi ilmiah ditambah dengan pendukung yang ada hampir di seluruh dunia, termasuk Indonesia. Tokohtokoh pengusung paham ini pun tidak semata-mata hanya berasal dari pengikut agama tertentu melainkan juga diusung oleh pakar-pakar sains.
Problematika konsep bentuk Bumi tentu membawa dampak terhadap ibadah umat Islam yaitu dalam hal penentuan arah kiblat dengan metode perhitungan: apakah menggunakan rumus segitiga bola dengan asumsi Bumi bulat (sferis), atau menggunakan formula Vincenty dengan asumsi bahwa Bumi berbentuk ellipsoid, atau menggunakan rumus trigonometri segitiga datar dengan asumsi Bumi datar.

Abdurrahim Khairullah Omar AshShareef (2014) dalam karyanya yang berjudul Aspects of Ancient Muslim Scholar's Induction Drawn from the Holy Quran in Proving Earth is Spherical mengkaji ayat-ayat Alquran yang berkaitan dengan bentuk Bumi. Ia memaparkan beberapa pendapat ulama yang memiliki 
pandangan yang sama seperti Ibn Taimiyah dan An-Nisaburi. Salah satu yang menonjol dari kajiannya adalah langit terdiri atas lapisan-lapisan dan begitu juga Bumi. Lapisan-lapisan ini dianalogikan dengan lapisan pada telur unggas. Adapun ayat yang berkaitan dengan ini adalah Q.S. AnNazi'at: 30 bahwa duhuw yang berarti memanjang berasal dari kata udhuya yang berarti sarang burung Onta. Sedangkan AdDuhya ialah telur burung Onta itu sendiri. Ini merupakan indikasi bahwa Bumi menyerupai bentuk telur yang berarti bentuknya bulat (Ash-Shareef, 2014: 216).

J. Ardian dkk menulis sebuah karya yang berjudul Benarkah Bumi Itu Datar? 100 Klaim Bukti Ilmiah Menurut Flat Earth Society dan Bantahannya. Tulisan ini merupakan kumpulan artikel-artikel dan buku-buku tentang sejarah, tokoh, dan pemikiran Bumi datar. Penyajiannya bersifat pengulangan (ringkasan) dari apa yang ditulis oleh penulis-penulis sebelumnya. Ringkasan yang dimaksud misalnya adalah tentang 100 bukti Bumi tidak bulat yang merupakan intisari dari buku 100 Proof the Earth is Not a Globe Karya William Carpenter (1885). Buku ini lebih berpihak pada kelompok Bumi datar karena merupakan paparan ulang atas kekuatan teori ini (J. Ardian dkk, 2017: 44).

Penelitian ini bertujuan mendeskrpsikan problematika teori Bumi bulat dan Bumi datar berdasarkan sains modern dan komunitas Bumi datar, perbedaan pendapat di antara ulama fikih mengenai bentuk Bumi, serta menjelaskan upaya dalam mencari titik temunya dalam penentuan arah kiblat. Dari perbedaan kedua konsep tersebut, penyusun beranggapan bahwa terdapat metode penentuan arah kiblat yang bebas dari pengaruh bentuk Bumi, apakah datar atau bulat. Metode yang dimaksud adalah rashdul kiblat tahunan.

\section{METODE PENELITIAN}

Penelitian ini merupakan penelitian kepustakaan (library research) yang datanya berasal dari sumber-sumber sekunder seperti buku dan jurnal ilmiah. Adapun analisis datanya menggunakan metode induktif yaitu membuat suatu kesimpulan/generalisasi dari beberapa fenomena khusus. Selain itu, pendekatan sains juga dilakukan dalam membantu analisis sehingga diperoleh suatu sintesis logis dari data-data deskriptif.

\section{PEMBAHASAN}

\section{A. Konsep Bumi Sferoid (Bola) dan Elipsoid}

Plato (427-347 SM) yakin bahwa Bumi itu bulat. Secara signifikan, dia tidak bisa membuktikan hal ini. Kemudian muridnya yaitu Aristoteles (384-322 SM) sekitar tahun 330 SM mulai menawarkan bukti bahwa Bumi berbentuk bola. Salah satu bukti yang meyakinkan yaitu dengan menunjukkan bentuk bayangan Bumi yang terlihat saat terjadi Gerhana Bulan. Menjelang awal Abad Pertengahan, pengetahuan bahwa Bumi itu bulat menyebar luas di seluruh Eropa.

Eksperimen ilmuan Yunani kuno yang sangat terkenal untuk membuktikan bahwa Bumi itu bulat berasal dari Eratosthenes (276-194 SM). Metodenya melibatkan pengamatan bayang-bayang yang dibentuk oleh Matahari di permukaan Bumi. Dalam eksperimennya, tongkat ditempatkan secara vertikal di atas tanah yang berada di kota Alexandria dan di Assouan (Syen). Kedua kota tersebut berada di lingkaran meridian yang sama. Karena lingkaran meridian merupakan lingkaran besar bagi bola langit, lingkaran-lingkaran Bumi yang berada di bawahnya juga merupakan lingkaran besar (Heath, 1991: 110).

Pada siang hari, sudut yang dibuat oleh sinar Matahari dan bagian atas stik diukur. Ditemukan bahwa ada perbedaan antara dua pengukuran. Sebagaimana diketahui bahwa Alexandria dan Assouan berada di garis bujur yang sama sehingga siang hari 
selalu terjadi pada saat yang sama persis di tempat-tempat itu. Ini berarti bahwa kedua kota tersebut pasti sesuai satu sama lain dengan arah Matahari pada saat itu. Dari hasil percobaannya, Eratosthenes menyimpulkan bahwa kota-kota itu tidak mungkin berada di permukaan datar melainkan harus berada di permukaan bola.

Teori Bumi paling modern saat ini adalah bahwa Bumi bukanlah bulat sempurna melainkan berupa ellips putar. Teori ini dikemukakan oleh French Academy of Sciences yang didirikan pada tahun 1666. Bentuk Bumi yang demikian karena adanya penggepengan pada kedua kutubnya sehingga menyebabkan besar jari-jari ke arah khatulistiwa lebih panjang dari pada yang ke arah kutub.

\section{B. Konsep Bumi Datar Era Modern}

Hipotesis modern yang mendukung teori Bumi datar dicetuskan oleh seorang ilmuwan asal Inggris, Samuel Rowbotham (1816-1884). Ia menjelaskan hasil temuannya sebagai bukti bahwa Bumi datar di dalam sebuah bukunya yang berjudul Zetetic Astronomy Earth Not a Globe. Ia juga mendirikan Zetetic Society yang terletak di Inggris dan Amerika Serikat. Rowbotham adalah ilmuan Bumi datar pertama yang memberikan hipotesis ukuran diameter Matahari sebesar 32 Mil dengan jaraknya dari Bumi sekitar 700 mil (J. Ardian dkk, 2017: 17).

Tokoh lain Bumi datar yang terkenal adalah John Hampden (18191891). Ia dengan penuh semangat mempromosikan ide Bumi datar di Inggris. Ia juga mendirikan komunitas Bumi datar yang bernama Truth Seeker's Oracle dan Scriptural Science Review pada tahun 1876. Selain Hampden, tokoh-tokoh dan ilmuan Bumi datar lainnya yang terkenal adalah William Carpenter (1830-1896), David Wardlaw Scott (1823-1901), Lady Blount (1850-1935), John
Alexander Dowie (1847-1907). E. Eschini, Charles Johnson,Wilbur Glenn Voliva (1870-1942), dan lain-lain (J. Ardian dkk, 2017: 18-19).

Gerakan komunitas Bumi datar di abad ke-20 kembali mengalami kebangkitan. Pada tahun 1952, S.G. Fowler menulis artikel yang berjudul Truth-The Earth is Flat. Kemudian pada tahun 1956, Samuel Shenton menghidupkan kembali UZS (Universal Zetetic Society) dan mengubah namanya menjadi The International Flat Earth Society (IFS). Setelah Shenton, presiden IFS digantikan oleh Charles K. Johnson. Johnson menerbitkan surat kabar yang bernama The International Flat Earth News yang bertujuan untuk mengembalikan kewarasan dunia. Johnson menggunakan otoritas Al-Kitab untuk menegaskan bahwa Bumi merupakan sebuah piringan datar (J. Ardian dkk, 2017: 37).

Para tokoh Bumi datar banyak mengambil dalil al-Kitab sebagai oenguat argumentasinya. Adapum dalil yang menjadi dasar argumen flat earthers dan masih digunakan hingga kini adalah beberapa di antaranya tercantum pada tulisan Robert J. Schwadewald di The Bulletin of the Tychonian Society berjudul The FlatEarth Bible. Schwadewald menuliskan beberapa ayat seperti Daniel 4:10-11 yang mengisahkan penguasa Babilonia, Raja Nebukadnezar, berkata "Saw a tree of great height at the centre of the earth... reaching with its top to the sky and visible to the earth's farthest bounds." (Melihat sebatang pohon yang amat tinggi di tengah Bumi... pohon itu tingginya mencapai ujung langit dan dapat terlihat dari titik Bumi paling jauh). Schwadewald menganggap bahwa pohon tersebut hanya bisa terlihat hingga ke ujung-ujung dunia apabila Bumi datar

Di dalam teori Bumi datar modern, Matahari dan Bulan memiliki 
ukuran yang sama dan kedua juga berputar mengelilingi Bumi yang tidak bergerak (tidak berotasi) seperti yang diabadikan dalam simbol Yin Yang China. Selain tidak berotasi, Bumi juga tidak melakukan gerakan revolusi (Rowbotham, 1881: 57). Matahari dan Bulan lebih dekat ke Bumi daripada yang diperkirakan sekarang dan masing-masing bersinar dengan cahaya unik. Menurut teori ini, Matahari berdiameter 32 mil dan berjarak sekitar 3.000 mil di atas permukaan Bumi.

Bulan memiliki jalan tahunan yang sama berputar di atas dan di sekitar Bumi namun tidak seperti Matahari, yang terus-menerus mengubah kecepatannya untuk mempertahankan 24 jam sehari yang konsisten, kecepatan Bulan tidak pernah berubah dan bergantung pada garis lintangnya yakni sekitar 24,7 - 25 jam per siklus. Inilah sebabnya mengapa pada waktu dan tempat yang berbeda selama setiap bulan kita bisa melihat Bulan di pagi hari, siang atau malam hari.

Menurut konsep Bumi datar, Matahari dan Bulan berada dalam kubah langit (dome) seperti gambar berikut.

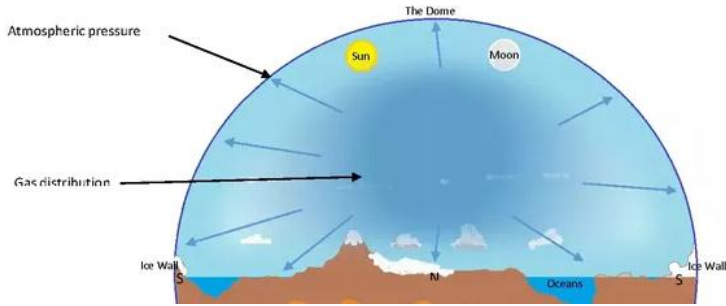

Gambar 1. Ilustrasi konsep flat earth.

Di dalam teori Bumi datar, Matahari selalu berada di atas permukaan Bumi. Gerakan Matahari terbit dan tenggelam dikarenakan perspektif penglihatan manusia. Ketika objek sangat jauh, maka ia akan tampak mendekati horizon seperti halnya balon udara (pesawat) yang menjauh dengan gerakan stabil tanpa mengubah ketinggiannya. Ini diibaratkan dengan lampu jalan yang ketinggiannya sama, jika dilihat hingga kejauhan akan semakin rendah di horizon. Begitu pula dengan Matahari. Posisi ketinggiannya yang sebenarnya adalah tetap jika dilihat dari Bumi akan tampak terbit, transit, dan terbenam dikarenakan perspektif akibat gerakannya yang berubah-ubah mendekat-menjauhi Bumi (Rowbotham, 1881: 108-109).

Karakteristik posisi Bumi, Matahari, dan Bulan termasuk gerakangerakannya di dalam teori FE ini menyebabkan penjelasan yang berbeda tentang gerhana. Gerhana Matahari terjadi karena Bulan melintas di antara Matahari dan Bumi. Namun, berbeda untuk gerhana Bulan. Menurut teori ini, gerhana Bulan terjadi sekitar dua kali setahun saat satelit Matahari melintas di antara Matahari dan Bulan. Satelit ini disebut objek bayangan. Bidang orbitnya miring dengan sudut sekitar $5^{\circ} 10^{\prime}$ terhadap bidang orbit Matahari, memungkinkan gerhana hanya jika tiga objek (Matahari, Objek, dan Bulan) sejajar dan saat bulan melintasi bidang orbit matahari (di sebuah titik yang disebut node). Dalam tahun tertentu, mengingat orbit benda langit ini, maksimal tiga gerhana bulan dapat terjadi. Terlepas dari kenyataan bahwa ada lebih banyak gerhana Matahari daripada gerhana bulan setiap tahun, dari waktu ke waktu semakin banyak gerhana bulan terlihat di satu lokasi di Bumi daripada gerhana matahari. Hal ini terjadi karena gerhana bulan bisa dilihat dari seluruh setengah permukaan Bumi di bawah bulan saat itu, sedangkan gerhana matahari hanya terlihat di sepanjang lintasan sempit di permukaan Bumi.

\section{Problematika Sains Berkaitan dengan Konsep Bentuk Bumi}

Berikut beberapa problematika sains yang diperselisihkan antara penganut FE dan saintis modern (sains Bumi bulat) berkaitan dengan konsep bentuk Bumi yaitu: 


\section{Kelengkungan (curvature) Bumi}

Sebuah eksperimen dalam rangka untuk membuktikan Bumi datar dilakukan oleh Samuel Birley Rowbotham (1816-1884) pada panas tahun 1838. Percobaan ini dilakukan di sebuah terusan sepanjang 20 mil yang disebut Old Bedford. Aliran airnya tidak terhambat oleh areal cekungan atau pintu air atau benda-benda apa pun sehingga sangat cocok untuk melihat apakah ada lengkungan Bumi atau tidak. Ia menggunakan sebuah teleskop yang ditempatkan 8 inci di atas permukaan air untuk mengamati sebuah kapal dengan tiang setinggi lima kaki yang bergerak perlahan menjauh darinya. Selama pengamatan ini, ia melaporkan bahwa kapal tersebut tetap berada dalam pandangannya secara penuh sejauh 6 mil. Menurutnya, jika Bumi berbentuk bola maka permukaan airnya telah melengkung dengan jarak tersebut (Rowbotham, 1881: 19).

Berdasarkan hasil hitungan para ahli yang mengatakan bahwa total luas lingkaran Bumi adalah 25.000 mil, seharusnya sebuah objek yang diamati sejauh 6 mil $(9.7 \mathrm{~km})$ sudah berada di belakang lengkungan Bumi (curvature). Tetapi berdasarkan percobaan Samuel Robowtham ini, kapal sebagai objek yang diamatinya masih dapat terlihat dengan jelas melalui teleskopnya.

Dari percobaannya ini, Robowtham ingin menjelaskan jika memang benar Bumi itu berbentuk bulat, tidak mungkin kapal tersebut yang jaraknya telah mencapai 6 mil masih dapat terlihat penuh walaupun menggunakan teleskop karena pada jarak tersebut objek yang diamati sudah berada di balik lengkungan Bumi.

Setelah eksperimen ini dilakukan, kritikan muncul dari angkatan laut bahwasanya percobaan Samuel Birley Rowbotham tidak menghitung refraksi cahaya oleh uap air laut yang pasti terjadi ketika temperatur sangat tinggi. Mengingat percobaan ini dilakukan saat musim panas, maka penguapan air laut pasti terjadi, dan akibatnya ialah refraksi cahaya (pembelokan cahaya) oleh uap air laut.

Seorang fisikawan lapangan bernama Alfred Russel Wallace akhirnya melakukan percobaan ini. Yang pertama ingin ia pastikan ialah menghindari efek refraksi cahaya oleh uap air laut maka dia melakukan percobaan yang sama tetapi pada ketinggian titik pengamatan $13 \mathrm{kaki}=4$ meter. Hasil dari percobaannya membuktikan bahwa bagian bawah kapal menghilang. Hasilnya berlawanan dengan yang diperoleh pada awal experimen Samuel Birley Rowbotham. Hasil ini diakui oleh kongres kemudian eksperimen yang sama telah dilakukan oleh orang lain dan memberikan hasil yang sama (kiblat.net, 2017).

2. Foto Bumi

Menurut pendapat flatter, foto Bumi yang beredar sekarang adalah rekayasa komputer CGI (Computergenerated imagery) alias kebohongan yang sengaja dilakukan NASA (National Aeronautics and Space Administration). Persoalan lain tentang foto Bumi adalah ketidakkonsistenan warna (citra) foto dan bentuk benua. Warna lautan bervariasi dan negara bervariasi ukurannya. Pada tahun 2012, daratan Amerika Serikat sangat besar sedangkan pada tahun 1997 dan 2002, Amerika Serikat jauh lebih kecil daripada yang seharusnya (NASA, 2017).

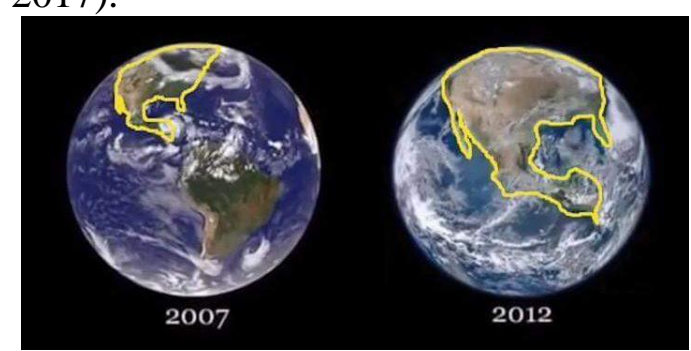

Gambar 2. Bantahan keaslian foto Bumi oleh komunitas FE

3. Jarak Matahari ke Bumi

Perhitungan jarak Matahari ke Bumi menjadi gerakan yang 
monumental bagi komunitas Bumi datar. Pada tanggal 23 September 2017 lalu, gerakan ini menjadi gerakan nasional yang dilakukan serempak di Indonesia. Perhitungan ini juga menjadi hasil riset yang dituangkan di Jurnal ilmiah FE101. Perhitungan jarak Matahari ke Bumi. Menurut versi Flat Earth (FE), hal itu disebabkan orbit Matahari mengelilingi Bumi tanggal 22 Juni mengecil di lingkar kutub utara $\left(23,5^{\circ}\right.$ LU) dan tanggal 22 Desember membesar di dekat Antartika $\left(23,5^{\circ}\right.$ LS). Sementara menurut versi globe earth (GE), hal itu disebabkan Bumi bola mengalami tilt (miring) $23,5^{\circ} \mathrm{LU}$ tanggal 22 Juni dan miring $23,5^{\circ}$ LS tanggal 22 Desember. Adapun metode perhitugannya adalah sebagai berikut.

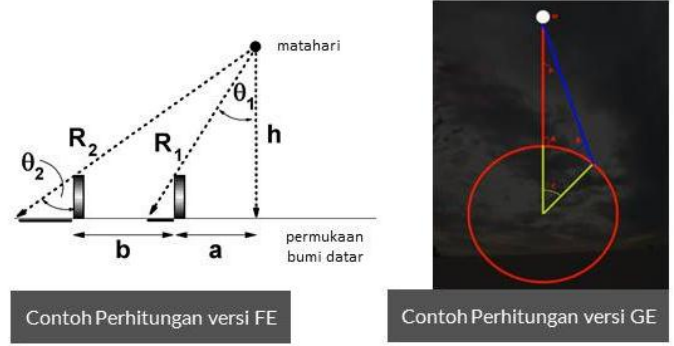

Gambar 3. Logika penentuan tinggi Matahari oleh komunitas FE101 (Boss Darling, 2017)

Adapun hasil analisis dari perhitungannya menghasilkan nilai rata-rata jarak Matahari ke Bumi sekitar $5.900 \mathrm{~km}$. Jarak Bumi ke Matahari menurut FE1010 ini sangat masuk akal jika dianggap Bumi bentuknya datar dengan ukuran Matahari berupa bola yang ukurannya sangat kecil mendekati sebuah titik, namun memiliki kekuatan sumber radiasi yang sangat besar sehingga memancar ke segala arah.

Namun, jika deskripsi terjadinya kulminasi di khatulistiwa dengan asumsi Bumi bulat dengan jarak Matahari sangat jauh maka hasilnya tidaklah demikian. Deskripsi letak Matahari yang sangat jauh ini menghasilkan arah bayangan ke Bumi seluruhnya sejajar.
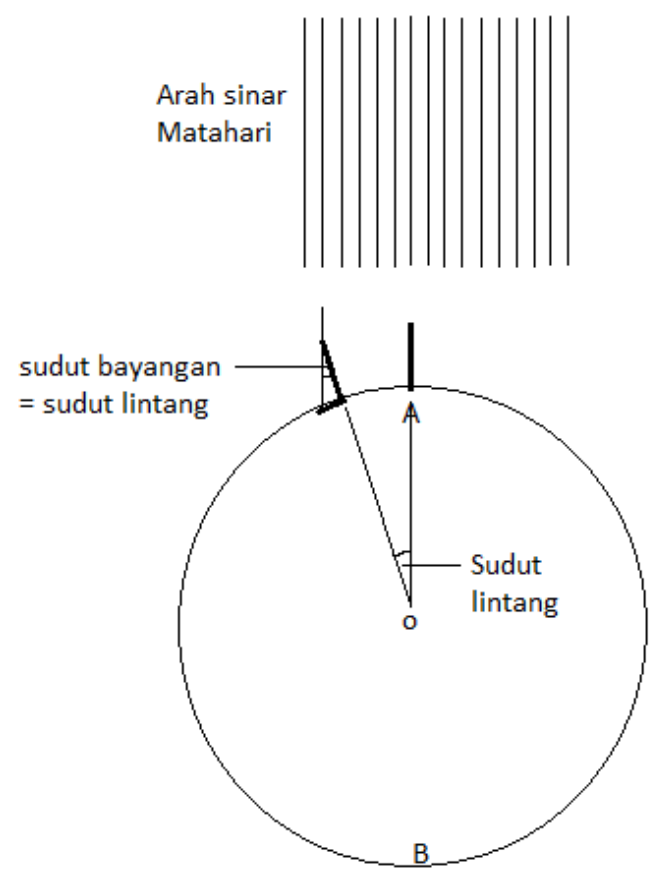

Gambar 4. Sudut bayangan menunjukkan lintang tempat pada bola Bumi

Ketika pengamatan dengan menegakkan gnomon (tongkat istiwa) di Pontianak dan tegaknya gnomon di Semarang (misalnya) tidaklah sama artinya. Arti kata tegak maksudnya adalah sejajar zenith. Oleh karena zenith pengamat di setiap lintang berbeda, tidak sejajar bahkan berlaku juga untuk bujur yang berbeda maka semkian jauh pengamatan bayangan tongkat pada saat kulminasi ini dari khatulistiwa semakin panjang pula bayangan gnomon ini. Terbentuknya bayangan gnomon pada lokasi lintang selain di Pontianak ini sangat dipengaruhi oleh kelengkungan Bumi sehingga menyebabkan zenith dua pengamat tersebut tidak sejajar dengan arah bayangan Matahari sehingga membentuk bayangan.

Berbeda dengan kata tegak jika dua benda yang ditempatkan pada bidang datar. Arti kata tegak di sini bermakna sama arahnya atau zenitnya saling sejajar. Dalam hal ini, perhitungan jarak Matahari ke Bumi dapat dilakukan. Sedangkan pada bidang yang melengkung, perhitungan 
perbandingan segitiga tidaklah berlaku sehingga tidak dapat dihitung jarak Matahari ke Bumi secara pasti.

Perbedaan mendasar antara konsep FE dan sains modern adalah jarak dan ukuran Matahari. Berdasarkan teori sains modern, jari-jari Matahari $696.000 \mathrm{~km}$ dengan jarak rata-rata ke Bumi 150.000.000 km (1 SA) (Admiranto, 2009, 23). Dengan ukuran dan Jarak seperti ini, maka arah sinar Matahari datangnya relatif sejajar walaupun Matahari seolah-olah tampak kecil jika diamati dari Bumi. Sedangkan menurut konsep FE, Matahari hanya berdiameter 32 mil dan berjarak sekitar 3.000 mil di atas permukaan Bumi.

\section{Upaya Mencari Titik Temu dalam Penentuan Arah Kiblat}

Walaupun sains modern menyatakan bahwa bentuk Bumi adalah bulat, namun menurut pandangan penganut Bumi datar tidak demikian. Mereka juga membantah dan berargumen dengan penjelasan sains. Masalah baru muncul di dalam masalah ibadah umat Islam yakni ketika akan menentukan arah kiblat.

Permasalahan ini tentu sangat urgen, karena bagi penganut Bumi ini bulat tentu akan mengarah kiblat dengan perhitungan segitiga bola. Lain lagi dengan teori bahwa Bumi diyakini tidak bulat bola melainkan sedikit pepat di kutub dan menggembung di katulistiwa. Sedangkan bagi penganut Bumi datar, tentu arah kiblat akan berbeda pula. Sejauh penelusuran penyusun, walaupun teori Bumi datar sudah memiliki peta dunia, namun teori ini belum memiliki sistem perhitungan koordinat di permukaan Bumi secara baku yang berkaitan dengan penerapannya dalam perhitungan arah kiblat. Akan tetapi, penentuan secara perkiraan (kasar) pada proyeksi peta Bumi datar masih dapat dilakukan. Hasilnya tentu tidak akurat. Ini terutama berkaitan dengan tata koordinat yang belum mapan.
Sekalipun NASA dengan segala teknologi ruang angkasanya yang begitu cangggih dan menjadi sumber informasi terpercaya bagi dunia astronomi, namun tetap saja tidak demikian pandangan kaum flat earther. Mereka tetap mempertanyakan kebenaran NASA bahkan membantah dengan alasan NASA telah membuat kebohongan dan manipulasi sains.

Menurut sains modern, bentuk ideal Bumi dimodelkan sebagai sebuah bola ellipsoid. Perhitungan arah kiblat dengan model ini dengan formula Vincenty pun sudah mulai diterapkan. Metode perhitungan ini pun dianggap sebagai perhitungan yang paling akurat saat ini. Namun, tidaklah demikian menurut Satrio Wicaksono, Moehammad Awaluddin, dan Hani'ah yang dituangkan di dalam penelitian mereka pada tahun 2016 yang berjudul Analisis Spasial Arah Kiblat Kota Semarang. Penelitian ini adalah komparasi antara tiga metode perhitungan arah kiblat pada bidang bola, ellipsoid, dan datar. Adapun hasil dari penelitian ini adalah besar arah kiblat pada bidang ellipsoida dengan metode hitungan vincenty yang sudah tereduksi sebesar $294^{\circ} 25^{\prime} 4.16^{\prime \prime}$ Untuk besar arah kiblat pada bidang bola dengan metode segitga bola lintang reduksi menghasilkan azimut kiblat sebesar 294' 26' 26.69". Sedangkan besar arah kiblat pada bidang datar sebesar $292^{\circ} 12^{\prime}$ 8.61". Berdasarkan hasil hitungan kiblat, nilai akurasi arah kiblat dari metode hitungan di ketiga bidang yang mempunyai derajat kedekatan terhadap metode rashdul kiblat tahunan yaitu nilai arah kiblat di bidang bola (Wicaksono, 2016).

Berdasarkan penelitian ini, tampak bahwa metode perhitungan arah kiblat yang paling akurat masih menimbulkan tanda tanya. Rashdul kiblat tahunan yang dijadikan acuan penentuan arah kiblat alamiah paling akurat memang telah teruji 
sebagaimana juga dinyatakan oleh Izzuddin di dalam penelitiannya. Namun, menurut penyusun, permasalahan arah kiblat apakah berkaitan dengan keyakinan seseorang atas sains atau atas tafsir ayat-ayat alQuran memang harus dimaklumi dan tetap ada benang merah sebagai titik temu bagaimana kedua penganut bentuk Bumi ini saling sefaham yaitu pada peristiwa rashdul kiblat tahunan.

Rashdul kiblat adalah ketentuan waktu di mana bayangan benda yang terkena sinar Matahari menunjuk arah kiblat. Sebagaimana dalam kalender menara kudus KH Turaichan di tetapkan tanggal 27 atau 28 Mei dan tanggal 15 atau 16 Juli pada tiap-tiap tahun sebagai "Yaumi Rashdul Kiblat" dengan melakukan pengamatan Matahari tepat berada di atas kakbah. Peristiwa rashdul kibkat tahunan ini menurut perhitungan terjadi setiap tanggal 28 Mei (untuk tahun Basitah) atau 27 Mei (untuk tahun kabisat) pada pukul 16:17:58.16 WIB, dan juga pada tanggal 15 Juli (untuk tahun basitah) atau 16 Juli (untuk tahun kabisat) pada pukul 16:26:12.11 WIB (Izzuddin, 2012: 45).

Penentuan arah kiblat menggunakan bayangan Matahari ini merupakan cara yang paling sederhana dan bebas hambatan. Hambatan terjadi kalau pada saat itu langit berawan. Dalam praktiknya, tidak perlu langkah yang rumit untuk menentukan arah kiblat berdasar jatuhnya bayangan benda yang disinari Matahari (Azhari, 2007: 54). Pada saat ini, seluruh bayangan benda yang tegak di Bumi dapat dipastikan mengarah ke Kota Makkah.

Menurut penulis, rashdul kiblat adalah satu-satunya metode penentuan arah kiblat yang bebas dari pengaruh bentuk Bumi. Dengan memaksimalkan peristiwa rashdul kiblat global ini, tentu akan mengurangi perselisihan dalam penentuan arah kiblat bagi penganut bentuk Bumi yang berbeda-beda. Untuk wilayah dekat kakbah, penentuan arah kiblat pada saat peristiwa ini dapat dilakukan dengan mudah karena Matahari masih cukup tinggi, misalnya untuk wilayah barat Indonesia. Namun, untuk wilayah tengah dan timur, ini menjadi masalah yang sulit diatasi jika hanya mengandalkan alam bahkan menjadi tidak mungkin untuk memanfaatkan momen ini. Ini dikarenakan pada saat Matahari berkulminasi di atas Makkah (Kakbah) di bagian tengah Indonesia waktu daerah sudah menunjukkan pukul sekitar 17.18 WITA sedangkan wilayah timur sudah pukul 18.18.

Untuk wilayah tengah, hal ini masih dapat diatasi dengan menggunakan bantuan peralatan teleskop. Model teleskop yang digunakan adalah teleskop yang secara otomatis dapat mengikuti pergerakan Matahari. Dengan cara seperti ini arah kiblatnya tidak menggunakan arah bayangan Matahari melainkan arah teleskop yang digunakan. Tentu kalibrasi awal dan persiapan settingan alat harus dilakukan dengan cermat agar teleskop benar-benar mengarah ke Matahari dan Matahari tepat berada di tengah-tengah teleskop saat diamati. Sedangkan untuk wilayah Timur, pengamatan sangat sulit dan bisa dikatakan tidak dapat dilakukan karena pada saat rashdul kiblat global, Matahari sudah di bawah ufuk. Hal ini tidak memungkinkan untuk dilaksanakannya pengamatan.

\section{E. Penutup}

Sebagai kesimpulan dari makalah ini adalah pertama, tidak terdapat nash syar'i baik al-Qur'an maupun hadis yang secara tegas menyatakan bentuk Bumi yang sebenarnya. Walaupun sains modern menyatakan Bumi berbentuk bola (sferoid maupun ellipsoid), namun hal ini dibantah oleh penganut flat earth yang mengklaim bahwa NASA terlah 


\begin{abstract}
menyebarkan pemberitaan palsu mengenai bentuk Bumi melalui teknologi satelitnya. Kedua, perbedaan konsep bentuk Bumi di kalangan umat Islam akan berdampak pada perbedaan penentuan arah kiblat. Berkaitan dengan permasalahan ini, salah satu upaya yang dapat dilakukan untuk mencari titik temu perbedaan konsep bentuk Bumi ialah dengan mengoptimalkan peristiwa rashdul kiblat tahunan. Rashdul kiblat tahunan dapat diajukan sebagai solusi dalam menentukan arah kiblat yang sifatnya tidak bergantung pada bentuk Bumi apakah datar, ellipsoid, atau bola. Untuk mengoptimalkan penentuan arah kiblat pada saat rashdul kiblat, salah satu upayanya adalah dengan menggunakan teleskop.

Sebagai saran dari hasil pembahasan makalah ini adalah penyusun menyarankan kepada MUI atau pihak yang berwenang untuk membuat fatwa tentang penentuan arah kiblat bagi muslim yang meyakini bentuk Bumi bulat (sferoid), datar, atau
\end{abstract} ellipsoid. 


\section{DAFTAR PUSTAKA}

Admiranto. A. Gunawan. Menjelajahi Tata Surya. Yogyakarta: Penerbit Kanisius, 2009.

Ardian, J. dkk. Benarkah Bumi itu datar? 100 Klaim Bukti Ilmiah Menurut Flar Earth Society dan bantahannya. Yogyakarta: Narasi, 2017.

Azhari, Susiknan, Ilmu Falak Perjumpaan Khazanah Islam dan Sains Modern, Yogyakarta: Suara Muhammadiyah, 2007.

Darling, Boss. "Gerakan Nasional Menghitung Jarak Matahari Versi Bumi Datar dan Bumi Globe 23 September 2017”, Press Release FE101 Community 21 September 2017.

Dubay, Eric. The Flat Earth Conspiracy (e-book).2014.

Heath, Sir Thomas L.. Greek Astronomy. New York: Dover Publication INC, 1991.

Izzuddin, Ahmad, Ilmu Falak Praktis, Semarang: PT. Pustaka Rizki Putra, 2012.

Kamaluddin, Husain, Ta'yiinu Awaaili Syuhuuril 'Arabiyyah bi Isti'maalil Hisabi, Cetakan ke-1, Riyadh: Daar 'Akaadz, 1979.

Rowbotham, Samuel Birley. Zetetic Astronomy Earth Not a Globe, London: 1881.

Wicaksono, dkk. "Analisis Spasial Arah Kiblat Kota Semarang". Jurnal Geodesi Undip Oktober 2016, Volume 5, Nomor 4, Tahun 2016 ( ISSN : 2337-845X).

\section{Sumber Artikel Internet:}

Magrane, G., SPAEA, The Flat-Earth/Round Earth Controversy, www.indiana.edu, 1986, diakses 15 Oktober 2017.

NASA, First Pictures of Earth From 100 Miles in Space, 1947, https://www.nasa.gov/multimedia/imagegallery/image_feature_1298.html, diakses tanggal 13 November 2017

https://www.kiblat.net 